\title{
IMPROVING METHODS OF FERTILITY AND HATCHING RESULTS IN NAKED NECK CHICKEN (SHARKASI) EGGS
}

\section{A. Abd El-Rahman}

Department of Animal and Poultry Production, Faculty of Agriculture, University of Assiut, Assiut

\section{SUMMARY}

A total number of 5030 hatching eggs were produced from three genotypes namely; homozygous naked neck (Na/Na), heterozygous naked neck (Na/na) and normal feathering (na/na) genotypes to investigate the effect of some treatments to reduce egg weight loss during storage and incubation which may contribute to the improvement of hatching results of Sharkasi chickens. The results are summarized as follow:

\section{1- Effect of packaging.}

- The Na/- birds exhibited higher egg weight loss during storage or incubation period as compared with na/na genotype. Packaging (versus non-packaged) of eggs reduced significantly $(P<0.01)$ egg weight loss.

- The differences due to genotype or packaging method on fertility was insignificant.

- Packaging reduced significantly $(P<0.01)$ the total embryonic mortality and improved hatchability by about 4\%. The Na/- birds exhibited a remarkable reduction in hatchability and most of losses in embryos occurred mainly during the last stage before hatching.

- A significant $(P<0.05)$ interaction between packaging and genotype was found where packaging improved hatchability of the $\mathrm{Na}$ - eggs by about $5.5 \%$ and $5.4 \%$ for the Na/Na and Na/na genotypes as compared with $0.9 \%$ for the na/na genotype.

2 - Effect of calcium level.

- Differences due to genotype or dietary calcium level on fertility were insignificant.

- High dietary calcium level (3.47\%) reduced significantly $(P<0.01)$ egg weight loss as compared with low dietary calcium (2.51\%). Also, it reduced the total embryonic mortality by about $3.80 \%$.

- Although, dietary calcium level did not affect hatchability, the birds receiving high dietary calcium had higher hatchability (82.5\%) than birds receiving low dietary calcium (79.7\%).

- The interaction between calcium level and genotype was significant $(P<0.05)$ where the hatchability from birds receiving high dietary calcium was $77.7 \%, 85.4 \%$, $84.4 \%$ for $\mathrm{Na} / \mathrm{Na}$, Na/na and na/na genotypes, respectively. The corresponding figures for birds receiving low dietary calcium level were $70.20 \%, 78 \%$ and $90.70 \%$.

It can be concluded that, packaging of eggs in polyethelene bags and feeding on high dietary calcium level (3.47\%) are effective means for reducing egg weight loss and hence improving the hatching ability of the naked neck birds.

Keywords: Na gene, packaging, calcium level, hatchability

Issued by The Egyptian Society of Animal Production 


\section{INTRODUCTION}

The naked neck gene $(\mathrm{Na})$ is widespread in unselected local populations and known by peasents at various areas in Upper Egypt as Sharkasi chickens. Recently, interest has increased concerning the $\mathrm{Na}$ gene due its apparent association with heat tolerance (Abd El-Rahman, 2000a,b,c).

A remarkable reduction in the reproductive ability of the naked neck birds $(\mathrm{Na} /-)$ especially in the homozygous form was reported (Abd El-Rahman, 1997, 2000a, 2003; Singh et al. 2001; Fathi, 2002 and Galal and Fathi, 2003). The mechanism that explains the reduction in hatching ability of the naked neck birds has not yet been identified. It is well documented that a slight disadvantage of naked neck birds was noticed for egg shell quality as measured by percentages of shell-less eggs and craked eggs, breaking strength and shell thickness (Abd El-Rahman, 2000b,c, 2003 and Singh et al., 2001).

Many investigators indicated that embryonic mortality was high in eggs with poor egg shell quality which related to egg water loss during storage and incubation periods which is considered as an important indicator for egg shell quality in hatching eggs (Rouqe and Soares, 1994; Shebl et al., 1996; Shebl and Soliman, 1999; Soliman, 2000 and Abd El-Rahman, 2003). Also, high correlation was found between egg weight loss during storage and shell thickness (Rouqe and Soares, 1994). Several studies have examined the relationship between shell thickness and hatchability of eggs by either direct measurement of shell thickness or via specific gravity (Peebles and Brake, 1987, Rouqe and Soares, 1994 and Peebles et al. 2001). These studies reported that eggs with thin shells or those having low specific gravity were associated with reduced viability and thereby decreased hatchability. Furthermore, the rate of water loss from eggs is inversely proportional to shell thickness.

Peebles et al. (2001) found that increased shell thickness was associated with increased incidence of early embryonic death, whereas a decline in egg shell weight coincided with an increase in egg weight loss during incubation periods. Rate of water loss during incubation is directly related to the rate of embryonic growth, prepipping oxygen consumption rate, metabolic rate and egg shell gas conductance. Also, breeds or strains differed in shell thickness, weight loss and hence hatchability (Shebl et al. 1996, Shebl and Soliman, 1999 and Abd El-Rahman, 2003).

Efforts to reduce egg water loss during storage or incubation periods have included many ways (Helmy and Debes. 1974; Menge et al., 1977; Abd El-Rahman, 1979; Bruzual et al., 2000 and Peebles et al., 2001). Egg packaging as a mean of decreasing egg weight loss have been studied by many workers. Lohchuba et al. (1971); Helmy and Debes (1974) and Abd El-Rahman (1979) reported that chicken, turkey and duck eggs stored in polyethylene or plastic bags was lower weight loss and higher hatchability than control eggs. However, Basent et al. (1974) indicated that packaging had no significant effect on hatchability.

On the other hand, it was reported that ideal dietary calcium level plays an important role in egg shell formation and quality which influence on the hatching ability of the eggs. Balloun and Miller (1964) used diets containing 1.5, 2, 2.5, 3\% calcium level for turkey hens and reported that the best hatchability was recorded when hens received diet with $2 \%$ or $2.5 \%$ whereas hatchability was depressed by 1.5 
and 3\% calcium level. Similar results were also obtained by Menge et al. (1977), Abd El-Rahman (1979) and Rouqe and Soares (1994).

The present work was conducted to investigate the reduction of egg weight loss and improving hatching ability of the naked neck birds (Sharkasi) either by egg treatment during storage (Packaging) or by one of managerial factors (dietary calcium level).

\section{MATERIALS AND METHODS}

This work was conducted at the Poultry Research Farm, Animal and Poultry Production Department, Assiut University, during the period from 2004 - 2005.

\section{Birds and Management}

Three genotypes were used in this study namely: homozygous naked neck $(\mathrm{Na} / \mathrm{Na})$, heterozygous naked neck $(\mathrm{Na} / \mathrm{na})$ and normal feathering $(\mathrm{na} / \mathrm{na})$ genotypes. Birds were raised in floor pens. The average environmental temperature and relative humidity (R.H.) were $22-25 \mathrm{C}^{\circ}$ and $60-65 \%$ during the experimental period. The sex ratio was 1:12, daily 14 hours lighting and ad libitum_feed and water were available.

Two experiments were carried out in this study.

\section{First experiment}

Birds were fed a ration contains $17 \%$ protein and $2840 \mathrm{ME}(\mathrm{k} \mathrm{cal} / \mathrm{kg})$. At $40-44$ wks of age a total number of 2370 hatching eggs from two successive batches was collected daily and randomly distributed equally into two groups: a- packaged group where eggs were weighed to the nearest $0.01 \mathrm{~g}$ and trayed in plastic trays, then placed in polyethylene bags, tied tightly and stored for 7 days in a reserving room under recommended conditions $\left(60 \mathrm{~F}^{\circ}\right.$ and $\left.75-80 \% \mathrm{R} . \mathrm{H}\right)$. b- control group or unpackaged eggs where eggs were weighed to the nearest $0.01 \mathrm{~g}$ and stored without packaging under the same storage conditions.

\section{Second experiment}

At 40-44 wk of age a total number of 2660 hatching eggs from 4 successive batches from birds of the three different genotypes were fed on two experimental diets differed in dietay calcium level presented in Table (1).

Before setting (after 7 days storage), all eggs in experiments 1 and 2 reweighed to calculate the storage weight loss. During incubation period, eggs were also reweighed at the $6^{\text {th }}$ and $18^{\text {th }}$ day of incubation to calculate the incubation weight loss percentage from the initial setting weight (weight after storage). All eggs were individually candled at the $6^{\text {th }}$ day, clear eggs and those having early dead embryos were recoded, broken and discarded.

B- Low dietary calcium level. Eggs were collected from birds received the other ration which contain $2.51 \%$ dietary calcium level, weighed and then stored.

At hatch, the number of chicks was recorded and unhatched eggs were broken and opened to determine the death age of the embryos and classified into four categories as follows:

Dead 1: Dead embryos from 1-6 days of incubation.

Dead 2: Dead embryos from 7-13 days of incubation.

Dead 3: Dead embryos from 14-18 days of incubation.

Dead 4: Dead embryos from 19-21 days of incubation which included dead in shell and pipped eggs. 
Table 1. Composition and analysis of diets (experiment 2)

\begin{tabular}{lcc}
\hline Ingredient (\%) & High calcium level & Low calcium level \\
\hline Ground yellow corn & 62.60 & 64.10 \\
Soybean meal & 17.00 & 17.00 \\
Gluten & 5.00 & 5.00 \\
Wheat bran & 5.00 & 6.00 \\
Vitamin mixture & 0.25 & 0.25 \\
Mineral mixture & 0.10 & 0.10 \\
Salt & 0.25 & 0.25 \\
Lysine & 0.20 & 0.20 \\
Methionine & 0.10 & 0.10 \\
Limestone & 7.50 & 5.00 \\
Bone meal & 2.00 & 2.00 \\
Calculated analysis & & \\
Crude protein \% & 16.97 & 17.10 \\
ME (k cal/kg) \% & 2850 & 2800 \\
Calcium \% & 3.47 & 2.51 \\
Phosphorus available \% & 0.37 & 0.37 \\
Phoshorus total \% & 0.61 & 0.63 \\
Salt \% & 0.33 & 0.33 \\
Crude fibers \% & 3.32 & 3.46 \\
Lysine \% & 0.94 & 0.95 \\
Methionine \% & 0.42 & 0.43 \\
Methionine + Cystine \% & 0.69 & 0.69 \\
\hline A $\%$ \% & &
\end{tabular}

A- High dietary calcium level. Eggs were collected from birds were fed on ration which contain $3.47 \%$ dietary calcium level and weighed to nearest $0.01 \mathrm{~g}$.

\section{Statistical analysis}

Data were subjected to the analysis of variance using the General Linear Models, (G.L.M.) Procedure SAS (SAS Institute, 1990) by the following model:

$$
\mathbf{Y}_{\mathrm{ijk}}=\boldsymbol{\mu}+\mathbf{G}_{\mathrm{i}}+\mathbf{T}_{\mathbf{j}}+(\mathbf{G x T})_{\mathrm{ij}}+\mathbf{E}_{\mathrm{ijk}}
$$

where $Y_{i j k}$ is the $k^{\text {th }}$ observation of the $i^{\text {th }}$ genotype and $j^{\text {th }}$ treatment, $\mu$ is the overall mean, $G_{i}$ is the effect of $i$ genotype, $T_{j}$ is the effect of $j^{\text {th }}$ treatment, $(G x T)_{i j}$ is the interaction effect of genotype with treatment and $\mathrm{E}_{\mathrm{ijk}}$ is the random error. Differences among means were assessed by using Duncan's Multiple Range Test (Steel and Torrie, 1980).

\section{RESULTS AND DISCUSSION}

\section{Effect of genotype and packaging on}

\section{Egg weight loss}

Results of packaging effect on egg weight loss per each genotype are presented in Table (2). The mean of egg weight loss during storage was significantly $(\mathrm{P}<0.01)$ associated with genotype, packaging and the interaction between them. The results exhibited that eggs from $\mathrm{Na} /$ - birds had recorded higher values of egg weight loss during storage than eggs from na/na genotype. It was $0.75 \%, 0.59 \%$ and $0.41 \%$ for $\mathrm{Na} / \mathrm{Na}, \mathrm{Na} / \mathrm{na}$ and na/na genotypes, respectively. These results are in agreement with the findings of Shebl and Soliman (1999) and Abd El-Rahman (2003) who reported 
that egg weight loss of $\mathrm{Na} /$ - at different storage periods was significantly higher than those obtained from na/na eggs.

Table 2. Means $(\bar{X}) \pm$ Standard errors (S.E) of egg weight loss during storage and incubation periods as affected by genotype (G) and packaging (P) in Sharkasi chickens

\begin{tabular}{|c|c|c|c|c|c|c|}
\hline \multirow[b]{2}{*}{ Factor } & \multirow[b]{2}{*}{ Group } & \multicolumn{3}{|c|}{ Storage weight loss } & \multicolumn{2}{|c|}{ Incubation loss \% } \\
\hline & & $\begin{array}{l}\text { Initial egg } \\
\text { weight (g) }\end{array}$ & $\begin{array}{c}\text { weight after } \\
\text { storage (g) }\end{array}$ & $\%$ loss & $\begin{array}{l}\text { From 1-6 } \\
\text { days }\end{array}$ & $\begin{array}{c}\text { From 1-18 } \\
\text { days }\end{array}$ \\
\hline \multirow{3}{*}{ (G) } & G1 & $46.67 \pm 0.19$ & $46.32^{\mathrm{B}} \pm 0.19$ & $0.75^{\mathrm{A}} \pm 0.02$ & $5.03^{\mathrm{A}} \pm 0.06$ & $12.92^{\mathrm{A}} \pm 0.14$ \\
\hline & G2 & $47.01 \pm 0.20$ & $46.73^{\mathrm{AB}} \pm 0.19$ & $0.59^{\mathrm{B}} \pm 0.02$ & $4.62^{\mathrm{B}} \pm 0.07$ & $12.38^{\mathrm{B}} \pm 0.17$ \\
\hline & G3 & $47.33 \pm 0.18$ & $47.14^{\mathrm{A}} \pm 0.18$ & $0.41^{\mathrm{C}} \pm 0.01$ & $4.32^{\mathrm{C}} \pm 0.07$ & $11.84^{\mathrm{C}} \pm 0.14$ \\
\hline \multirow{2}{*}{ (P) } & $\mathrm{P} 1$ & $46.87 \pm 0.15$ & $46.63 \pm 0.15$ & $0.50^{\mathrm{B}} \pm 0.01$ & $4.57^{\mathrm{B}} \pm 0.05$ & $12.12^{\mathrm{B}} \pm 0.12$ \\
\hline & $\mathrm{P} 2$ & $47.14 \pm 0.16$ & $46.82 \pm 0.11$ & $0.67^{\mathrm{A}} \pm 0.02$ & $4.75^{\mathrm{A}} \pm 0.06$ & $12.63^{\mathrm{A}} \pm 0.13$ \\
\hline \multirow{6}{*}{$(\mathrm{G} \times \mathrm{P})$} & $\mathrm{G}_{1} \times \mathrm{P}_{1} 400^{* * *}$ & $46.58 \pm 0.27$ & $46.26 \pm 0.26$ & $0.67^{\mathrm{AB}} \pm 0.62$ & $5.00 \pm 0.08$ & $12.68 \pm 0.19$ \\
\hline & $\mathrm{G}_{1} \times \mathrm{P}_{2} 390$ & $46.75 \pm 0.28$ & $46.36 \pm 0.27$ & $0.83^{\mathrm{A}} \pm 0.03$ & $5.06 \pm 0.09$ & $13.15 \pm 0.21$ \\
\hline & $\mathrm{G}_{2} \times \mathrm{P}_{1} 400$ & $47.12 \pm 0.27$ & $46.90 \pm 0.26$ & $0.46^{\mathrm{B}} \pm 0.02$ & $4.47 \pm 0.10$ & $12.0 \pm 0.21$ \\
\hline & $\mathrm{G}_{2} \times \mathrm{P}_{2} 400$ & $46.89 \pm 0.29$ & $46.56 \pm 0.29$ & $0.72^{\mathrm{A}} \pm 0.02$ & $4.78 \pm 0.08$ & $12.75 \pm 0.26$ \\
\hline & $\mathrm{G}_{3} \times \mathrm{P}_{1} 390$ & $46.90 \pm 0.26$ & $46.73 \pm 0.26$ & $0.37^{\mathrm{B}} \pm 0.01$ & $4.24 \pm 0.08$ & $11.68 \pm 0.20$ \\
\hline & $\mathrm{G}_{3} \times \mathrm{P}_{2} 390$ & $47.75 \pm 0.27$ & $47.54 \pm 0.27$ & $0.45^{\mathrm{B}} \pm 0.01$ & $4.40 \pm 0.10$ & $11.98 \pm 0.20$ \\
\hline ANOVA & d.f & & & Probabilities & & \\
\hline (G) & 2 & N.S. & $* *$ & $* *$ & $* *$ & $* *$ \\
\hline$(\mathrm{P})$ & 1 & N.S. & N.S. & $* *$ & $* *$ & $* *$ \\
\hline$G \times P$ & 2 & N.S. & N.S. & $* *$ & N.S. & N.S. \\
\hline Error & 2364 & & & & & \\
\hline $\begin{array}{l}\text { A,B, Mean } \\
(\mathrm{P}<0.05) \text {. } \\
\text { Homozygo }\end{array}$ & $\begin{array}{l}\text { within the same } \\
\text { N.S. = Not } \\
\text { naked neck (N) }\end{array}$ & $\begin{array}{l}\text { ctor within co } \\
\text { snificant; **P } \\
\mathrm{Na}\end{array}$ & $\begin{array}{l}\text { nn having diffe } \\
.01 . \mathrm{G} 1=\text { Hete }\end{array}$ & $\begin{array}{l}\text { t superscripts a } \\
\text { ygous naked ne }\end{array}$ & $\begin{array}{l}\text { ignificantly di } \\
(\mathrm{Na} / \mathrm{na}) \mathrm{G} 2\end{array}$ & $\begin{array}{l}\text { erent } \\
\quad=\end{array}$ \\
\hline $\mathrm{P} 1=\mathrm{Packa}$ & ed $\quad$ P2 $=$ Unpa & $\operatorname{aged} \mathrm{G} 3=$ No & al feathering ( $\mathrm{n}$ & & hatched egg & \\
\hline
\end{tabular}

The results also showed that egg weight loss during storage was reduced significantly by packaging where it was $0.50 \%$ and $0.67 \%$ in packaged and unpackaged eggs, respectively. The obtained results are in accordance with that reported by Helmy and Debes (1974) and Abd El-Rahman (1979). The interaction between genotypes and packaging exhibited a highly significant effect $(\mathrm{P}<0.01)$, the $\mathrm{Na} /$ - eggs recorded the highest egg weight loss and these values were $0.67 \%, 0.46 \%$ and $0.37 \%$ in packaged eggs from $\mathrm{Na} / \mathrm{Na}, \mathrm{Na} / \mathrm{na}$ and na/na genotypes, respectively. The corresponding values were $0.83,0.72$ and $0.45 \%$ in unpackaged eggs, respectively. It is observed that the lowest egg weight loss \% during 7 days of storage was recorded for packaging eggs from na / na birds.

Egg weight loss percentage of $\mathrm{Na} /$ - eggs was also higher during incubation periods. As shown in Table (2) the presence of $\mathrm{Na}$ gene led to a significant $(\mathrm{P}<0.01)$ increase in egg weight loss during the first 6 days of incubation, where it was $5.03 \%$, $4.62 \%$ and $4.32 \%$ in eggs from $\mathrm{Na} / \mathrm{Na}, \mathrm{Na} /$ na and na/na genotypes, respectively. The same effect was also found at the $18^{\text {th }}$ day of incubation where the percentages were $12.92 \%, 12.38 \%$ and $11.84 \%$ in the same mentioned genotypes, respectively. The obtained results were similar to that reported by Shebl and Soliman (1999) and Abd El-Rahman (2003). In contrast, Fathi (2002) and Galal and Fathi (2003) found that egg weight loss till 18 days of incubation was less in eggs from $\mathrm{Na} / \mathrm{na}$ than that obtained from their normal feathering genotype (na/na). 
The high values of egg weight loss due to the presence of $\mathrm{Na}$ gene is difficult to explain but it may partially due to the result of unregulated water loss as a result of some functional differences such as albumen quality or other physical attributes of the egg shell. It was proven that high egg weight loss from the $\mathrm{Na} /-$ eggs was correlated with the remarkable reduction in egg shell quality (Abd El-Rahman, 2003).

On the other hand, the high egg weight loss due to Na gene may be also attributed to its effect on cuticle structure (Peebles et al., 1987) or shell membrane structure which plays an important role in controlling egg weight loss especially when storage period increase (Shebl and Soliman, 1999). Tullett (1990) suggested that, it is possible that the developing embryos are able to tolerate a range of water losses from the egg. However, the differences in egg weight loss indicate that each breed or strain had ideal level of weight loss in order to maximize embryos survival.

Table 2 shows that packaging of eggs significantly reduced $(\mathrm{P}<0.01)$ egg loss during incubation periods. During the first 6 days of incubation the egg weight loss was $4.57 \%$ for packaged vs $4.75 \%$ for unpackaged eggs. At 18 days of incubation the corresponding values were $12.12 \%$ and $12.63 \%$ for packaged and unpackaged eggs, respectively. It appears that the rate of water loss from unpackaged eggs may have been increased above the optimum range of water loss required for growth and survival of embryo at late stage of incubation (Davis and Ackerman, 1987).

\section{b - Hatching results}

As presented in Table (3), the interaction between genotype and packaging was insignificant for all traits studied except TDE and hatchability. Although, fertility percentage of na/na was higher than that obtained from $\mathrm{Na} /$ - birds the differences between genotypes were insignificant. Fertility was $95.9 \%, 95.5 \%$ and $97.5 \%$ for the $\mathrm{Na} / \mathrm{Na}, \mathrm{Na} /$ na and na/na genotype, respectively. also, packaging treatment of eggs did not affect the percentage of fertile eggs (Table 3 ).

The presence of $\mathrm{Na}$ gene significantly $(\mathrm{P}<0.01)$ increased the total embryonic mortality by about $10.80 \%$ and $7.60 \%$ in eggs from $\mathrm{Na} / \mathrm{Na}$ and $\mathrm{Na} /$ na genotypes, respectively as compared to na/na genotype. The results showed that peaks of embryonic mortality were found from 19-21 days (dead 4) and from 1-6 days (dead 1) of incubation. More increase in embryonic mortality at early and late of the incubation period due to $\mathrm{Na}$ gene support the findings of Abd El-Rahman (1997, 2000a, 2003) who reported that most of losses in embryos occured mainly during the last stage before hatching. The hatchability was $76 \%, 79.20 \%$ and $86.80 \%$ in $\mathrm{Na} / \mathrm{Na}$, $\mathrm{Na} /$ na and na/na genotypes, respectively with significant $(\mathrm{P}<0.01)$ differnces btween them (Table 3).

Packaging of hatching eggs improved hatchability $(\mathrm{P}<0.01)$ by about $4 \%$. Menge et al. (1977) and Abd El-Rahman (1979) found that the use of plastic bags for packaging of hatching eggs reduced occurrence dead embryos, decreased markedly moisture loss and $\mathrm{Co}_{2}$ from them and hence increased their hatchability. The best hatchability was also found in the group of the lowest egg weight loss (Packaged eggs). The decrease in hatching power by increasing egg weight loss may be due to the increase in evaporation as the shell thickness decrease especially in the $\mathrm{Na} /$ genotypes (Abd El-Rahman, 2003). 


\begin{tabular}{|c|c|c|c|c|c|c|c|c|c|c|}
\hline Factor & Group & Fertility \% & Dead 1\% & Dead 2\% & Dead 3\% & Dead 4\% & Dead in shell \% & Pipped eggs \% & TDE\% & Hatchability \% \\
\hline \multirow{3}{*}{ (G) } & G1 & $95.9 \pm 1.0$ & $6.6 \pm 0.6$ & $1.4 \pm 0.1$ & $2.3 \pm 0.3$ & $13.7^{\mathrm{A}} \pm 1.0$ & $9.2^{\mathrm{A}} \pm 0.7$ & $4.5 \pm 0.8$ & $24.0^{\mathrm{A}} \pm 1.6$ & $76.0^{\mathrm{C}} \pm 1.6$ \\
\hline & $\mathrm{G} 2$ & $95.5 \pm 0.6$ & $4.8 \pm 1.2$ & $1.5 \pm 0.5$ & $2.1 \pm 0.5$ & $12.4^{\mathrm{A}} \pm 0.7$ & $7.6^{\mathrm{A}} \pm 0.4$ & $4.8 \pm 0.6$ & $20.8^{\mathrm{B}} \pm 1.6$ & $79.20^{\mathrm{B}} \pm 1.6$ \\
\hline & G3 & $97.5 \pm 0.1$ & $3.2 \pm 0.3$ & $1.2 \pm 0.5$ & $2.4 \pm 0.3$ & $6.5^{\mathrm{B}} \pm 0.3$ & $1.9^{\mathrm{B}} \pm 0.9$ & $4.6 \pm 0.9$ & $13.20^{\mathrm{C}} \pm 0.3$ & $86.80^{\mathrm{A}} \pm 0.3$ \\
\hline \multirow{2}{*}{ (P) } & P1 & $96.9 \pm 0.4$ & $4.2 \pm 0.8$ & $1.2 \pm 0.1$ & $2.0 \pm 0.3$ & $10.2 \pm 1.4$ & $5.7 \pm 1.3$ & $4.5 \pm 0.4$ & $17.4^{\mathrm{B}} \pm 1.6$ & $82.60^{\mathrm{A}} \pm 1.6$ \\
\hline & P2 & $95.6 \pm 0.8$ & $5.5 \pm 0.9$ & $1.8 \pm 0.3$ & $2.4 \pm 0.2$ & $11.6 \pm 1.7$ & $6.8 \pm 1.6$ & $4.8 \pm 0.5$ & $21.3^{\mathrm{A}} \pm 2.5$ & $78.70^{\mathrm{B}} \pm 2.5$ \\
\hline \multirow{6}{*}{$(\mathrm{G} \times \mathrm{P})$} & $\mathrm{G}_{1} \mathrm{XP}_{1}$ & $97.3 \pm 1.0$ & $6.0 \pm 0.6$ & $1.3 \pm 0.2$ & $1.9 \pm 0.5$ & $12.1 \pm 0.6$ & $8.1 \pm 0.3$ & $4.0 \pm 1.1$ & $21.3^{\mathrm{AB}} \pm 0.4$ & $78.70^{\mathrm{AB}_{ \pm} 0.4}$ \\
\hline & $\mathrm{G}_{1} \mathrm{XP}_{2}$ & $94.4 \pm 1.1$ & $7.3 \pm 1.1$ & $1.5 \pm 0.1$ & $2.6 \pm 0.4$ & $15.4 \pm 0.1$ & $10.4 \pm 0.7$ & $4.0 \pm 1.7$ & $26.8^{\mathrm{A}} \pm 0.5$ & $73.20^{\mathrm{C}} \pm 0.5$ \\
\hline & $\mathrm{G}_{2} \mathrm{xP}_{1}$ & $95.9 \pm 0.4$ & $3.6 \pm 1.3$ & $0.8 \pm 0.1$ & $1.4 \pm 0.6$ & $12.3 \pm 1.6$ & $7.1 \pm 0.5$ & $5.2 \pm 1.0$ & $18.1^{\mathrm{B}} \pm 0.2$ & $81.90^{\mathrm{AB}} \pm 0.2$ \\
\hline & $\mathrm{G}_{2} \times \mathrm{P}_{2}$ & $95.0 \pm 1.4$ & $5.9 \pm 2.8$ & $2.3 \pm 0.6$ & $2.8 \pm 0.4$ & $12.5 \pm 0.5$ & $8.0 \pm 0.3$ & $4.5 \pm 0.8$ & $23.5^{\mathrm{AB}} \pm 1.3$ & $76.50^{\mathrm{B}} \pm 1.3$ \\
\hline & $\mathrm{G}_{3} \times \mathrm{P}_{1}$ & $97.5 \pm 0.3$ & $3.0 \pm 1.0$ & $0.8 \pm 0.1$ & $2.8 \pm 0.2$ & $6.2 \pm 1.3$ & $1.9 \pm 1.1$ & $4.3 \pm 0.2$ & $12.8^{\mathrm{C}} \pm 0.1$ & $87.20^{\mathrm{A}} \pm 0.1$ \\
\hline & $\mathrm{G}_{3} \times \mathrm{P}_{2}$ & $97.5 \pm 0.1$ & $3.4 \pm 0.7$ & $1.5 \pm 0.7$ & $1.9 \pm 0.1$ & $6.9 \pm 1.7$ & $1.9 \pm 1.1$ & $5.0 \pm 0.6$ & $13.7^{\mathrm{C}} \pm 0.3$ & $86.30^{\mathrm{A}} \pm 0.3$ \\
\hline ANOVA & d.f & \multicolumn{9}{|c|}{ Probabilities } \\
\hline (G) & $\frac{2}{2}$ & N.S. & N.S. & N.S. & N.S. & $* *$ & $* *$ & N.S. & *** & $* *$ \\
\hline (P) & 1 & N.S. & N.S. & N.S. & N.S. & N.S. & N.S. & N.S. & ** & ** \\
\hline GxP & 2 & N.S. & N.S. & N.S. & N.S. & N.S. & N.S. & N.S. & * & * \\
\hline Error & 6 & & & & & & & & & \\
\hline \multicolumn{11}{|c|}{$\begin{array}{l}\text { A,B, Means within the same factor within column having different superscripts are significantly different }(\mathrm{P}<0.05) \text {. } \\
\text { N.S. }=\text { Not significant, } * \mathrm{P}<0.05 ; * * \mathrm{P}<0.01 \text {. }\end{array}$} \\
\hline \multirow{2}{*}{\multicolumn{4}{|c|}{$\mathrm{G} 1=$ Heterozygous naked neck $(\mathrm{Na} / \mathrm{na})$}} & \multirow{2}{*}{\multicolumn{3}{|c|}{$\begin{array}{l}\mathrm{P} 1=\text { Packaged } \\
\mathrm{P} 2=\text { Unnackaged }\end{array}$}} & & & & \\
\hline \multirow{2}{*}{\multicolumn{4}{|c|}{$\begin{array}{l}\text { G2 }=\text { Homozygous naked neck }(\mathrm{Na} / \mathrm{Na}) \\
\text { G3 }=\text { Normal feathering }(\mathrm{na} / \mathrm{na})\end{array}$}} & & Inpackaged & & & & & \\
\hline & & & & & & & & & & \\
\hline
\end{tabular}


A significant effect $(\mathrm{P}<0.05)$ on both TDE \% and hatchability due to the interaction between genotype and packaging was detected, where the packaging decreased TDE and improved hatchability of the eggs of the $\mathrm{Na} /-$ birds than those from their normal counterparts (na/na). The hatchability improvement due to packaging was $5.5 \%$ and $5.4 \%$ for the $\mathrm{Na} / \mathrm{Na}$ and $\mathrm{Na} /$ na whereas, it was only $0.9 \%$ for the na/na genotype.

From the above discussion, it may be concluded that using of polyethylene bags for packaging Sharkasi hatching eggs significantly reduces weight loss and hence increased their hatchability.

\section{Effect of genotype and calcium level on \\ Egg weight loss}

The results of dietary calcium level on weight loss per each genotype are presented in Tables (4). The mean of egg weight loss during storage was associated significantly $(\mathrm{P}<0.01)$ with genotype. It was $0.74 \%, 0.71 \%$ and $0.62 \%$ for the $\mathrm{Na} / \mathrm{Na}$, $\mathrm{Na} /$ na and na/na genotypes, respectively. Also, the weight loss of eggs from birds received high dietary calcium level was $0.67 \%$ vs. $0.73 \%$ of eggs from birds received low dietary calcium level but the difference was insignificant.

With regard to egg weight loss during incubation periods, it was observed that both genotype and dietary calcium level affect significantly $(\mathrm{P}<0.01)$ on egg weight loss. At the $6^{\text {th }}$ day of incubation, the $\mathrm{Na} / \mathrm{Na}$ genotype exhibited the highest value of egg weight loss (5.05\%) followed by $\mathrm{Na} / \mathrm{na}(4.52 \%)$ and finally na/na $(4.51 \%)$ genotype. Similar trend was also obtained at the $18^{\text {th }}$ day of incubation where the percentage of egg weight loss was $12.49 \%, 12.14 \%$ and $11.40 \%$ for the $\mathrm{Na} / \mathrm{Na}, \mathrm{Na} / \mathrm{na}$ and na/na genotypes, respectively.

High dietary calcium level reduced significantly $(\mathrm{P}<0.01)$ egg weight loss during incubation period where it was $4.56 \%$ and $11.73 \%$ at the 6 and 18 days of incubation, respectively. The corresponding values of egg weight loss from birds received low dietary calcium were $4.82 \%$ and $12.28 \%$ at the same two ages, respectively. Menge et al. (1977) showed that the decrease of egg weight loss during incubation period improved hatchability of chicken eggs. They also found that weight loss of eggs during the first seventh days of incubation was greater in eggs from hens fed $1.16 \%$ calcium level than that eggs from hens fed higher levels of calcium. Similar findings were also obtained by Abd El-Rahman (1979). Nestor et al. (1972) reported that high levels of calcium reduced shell porosity but did not significantly affect the hatchability of fertile eggs.

\section{Hatching results}

Results presented in Table (5) show that the interaction between genotype and calcium level had no effect on most of the traits studied except the dead 3, TDE and hatchability percentages.

As previous discussed, the results showed that $\mathrm{Na} /-$ birds were lower in fertility than na/na, where fertility was $96.20 \%, 96.70 \%$ and $98.10 \%$ in $\mathrm{Na} / \mathrm{Na}, \mathrm{Na} / \mathrm{na}$ and $\mathrm{na} /$ na genotypes, respectively, with no significant differences. Also, calcium level did not significantly affect fertility which was $97.6 \%$ for birds received high dietary calcium level vs $96.50 \%$ for birds receiving low dietary calcium level. These results are in agreement with those reported by Cherry et al. (1984) and Hasb El-Naby (1989) who reported that dietary Ca level did not affect percentage fertility. 
Table 4. Means $(\bar{X}) \pm$ Standard errors (S.E) of egg weight loss during storage and incubation periods as affected by genotype (G) and dietary calcium level (T) in Sharkasi chickens

\begin{tabular}{|c|c|c|c|c|c|c|}
\hline \multirow[b]{2}{*}{ Factor } & \multirow[b]{2}{*}{ Group } & \multicolumn{3}{|c|}{ Storage weight loss } & \multicolumn{2}{|c|}{ Incubation loss \% } \\
\hline & & $\begin{array}{l}\text { Initial egg } \\
\text { weight (g) }\end{array}$ & $\begin{array}{c}\text { weight after } \\
\text { storage (g) }\end{array}$ & $\%$ loss & From 1-6 days & From 1-18 days \\
\hline \multirow{3}{*}{ (G) } & G1 & $47.72 \pm 0.27$ & $47.37 \pm 0.27$ & $0.74^{\mathrm{A}} \pm 0.04$ & $5.05^{\mathrm{A}} \pm 0.08$ & $12.49^{\mathrm{A}} \pm 0.12$ \\
\hline & $\mathrm{G} 2$ & $47.64 \pm 0.25$ & $47.30 \pm 0.25$ & $0.71^{\mathrm{A}} \pm 0.02$ & $4.52^{\mathrm{B}} \pm 0.07$ & $12.14^{\mathrm{A}} \pm 0.10$ \\
\hline & G3 & $47.90 \pm 0.22$ & $47.60 \pm 0.24$ & $0.62^{\mathrm{B}} \pm 0.01$ & $4.51^{\mathrm{B}} \pm 0.08$ & $11.40^{\mathrm{B}} \pm 0.17$ \\
\hline \multirow{2}{*}{ (T) } & P1 & $47.54 \pm 0.21$ & $47.21 \pm 0.21$ & $0.67 \pm 0.03$ & $4.56^{\mathrm{B}} \pm 0.06$ & $11.73^{\mathrm{B}} \pm 0.13$ \\
\hline & P2 & $47.90 \pm 0.20$ & $47.62 \pm 0.19$ & $0.73 \pm 0.02$ & $4.82^{\mathrm{A}} \pm 0.07$ & $12.28^{\mathrm{A}} \pm 0.09$ \\
\hline \multirow{5}{*}{$(\mathrm{G} \times \mathrm{T})$} & $\mathrm{G}_{1} \mathrm{XP}_{1} 450^{* * * *}$ & $47.83 \pm 0.38$ & $47.48 \pm 0.37$ & $0.73 \pm 0.08$ & $4.83 \pm 0.11$ & $12.20 \pm 0.20$ \\
\hline & $\mathrm{G}_{1} \mathrm{xP}_{2} \quad 440$ & $47.61 \pm 0.34$ & $47.25 \pm 0.33$ & $0.76 \pm 0.03$ & $5.26 \pm 0.11$ & $12.77 \pm 0.13$ \\
\hline & $\mathrm{G}_{2} \mathrm{xP}_{2} \quad 450$ & $48.31 \pm 0.31$ & $47.95 \pm 0.31$ & $0.74 \pm 0.03$ & $4.50 \pm 0.12$ & $12.27 \pm 0.17$ \\
\hline & $\mathrm{G}_{3} \mathrm{xP}_{1} \quad 440$ & $47.80 \pm 0.35$ & $47.52 \pm 0.35$ & $0.58 \pm 0.01$ & $4.32 \pm 0.11$ & $10.99 \pm 0.29$ \\
\hline & $\mathrm{G}_{3} \times \mathrm{P}_{2} \quad 440$ & $48.00 \pm 0.34$ & $47.68 \pm 0.34$ & $0.67 \pm 0.02$ & $4.69 \pm 0.10$ & $11.80 \pm 0.10$ \\
\hline ANOVA & d.f & \multicolumn{5}{|c|}{ Probabilities } \\
\hline (G) & 2 & N.S. & N.S. & $* *$ & $* *$ & $* *$ \\
\hline (T) & 1 & N.S. & N.S. & N.S. & $* *$ & $* *$ \\
\hline $\mathrm{GxT}$ & 2 & N.S. & N.S. & N.S. & N.S. & N.S. \\
\hline Error & 2654 & & & & & \\
\hline
\end{tabular}

A,B, Means within the same factor within column having different superscripts are significantly different $(\mathrm{P}<0.05)$.

N.S. $=$ Not significant, $* * \mathrm{P}<0.01$.

$\mathrm{G} 1=$ Heterozygous naked neck $(\mathrm{Na} / \mathrm{na}) \quad \mathrm{T} 1=$ High calcium level $(3.47 \%)$

$\mathrm{G} 2=$ Homozygous naked neck $(\mathrm{Na} / \mathrm{Na}) \quad \mathrm{T} 2=$ Low calcium level $(2.51 \%)$

G3 = Normal feathering $(\mathrm{na} / \mathrm{na}) \quad \quad \quad$ N $\quad$ Number of hatched eggs. 
Table 5. Means $(\overline{\mathrm{X}}) \pm$ Standard errors (S.E.) of hatching results as affected by genotype (G) and dietary calcium level (T) in Sharkasi chickens

\begin{tabular}{|c|c|c|c|c|c|c|c|c|c|c|}
\hline Factor & Group & Fertility \% & Dead 1\% & Dead2\% & Dead 3\% & Dead 4\% & Dead in shell \% & Pipped \% eggs & TDE\% & Hatchability \% \\
\hline \multirow{3}{*}{ (G) } & G1 & $96.2 \pm 0.6$ & $6.2 \mathrm{~A} \pm 0.7$ & $1.6 \pm 0.4$ & $3.6 \pm 0.8^{\mathrm{A}}$ & $14.7^{\mathrm{A}} \pm 1.8$ & $8.0^{\mathrm{A}} \pm 1.2$ & $6.7^{\mathrm{A}} \pm 0.8$ & $26.0 \pm 2.6^{\mathrm{A}}$ & $74.0 \pm 2.6^{\mathrm{C}}$ \\
\hline & G2 & $96.7 \pm 0.7$ & $4.8 \mathrm{~A} \pm 0.9$ & $1.6 \pm 0.4$ & $2.0 \pm 0.4^{\mathrm{B}}$ & $9.9^{\mathrm{B}} \pm 1.3$ & $5.3^{\mathrm{B}} \pm 0.9$ & $4.6^{\mathrm{AB}} \pm 0.7$ & $18.2 \pm 1.8^{\mathrm{B}}$ & $81.8 \pm 1.8^{\mathrm{B}}$ \\
\hline & G3 & $98.1 \pm 0.4$ & $2.8 \mathrm{~B} \pm 0.2$ & $1.7 \pm 0.3$ & $2.2 \pm 0.5^{\mathrm{B}}$ & $6.9^{\mathrm{C}} \pm 1.1$ & $2.9^{\mathrm{C}} \pm 0.8$ & $4.0^{\mathrm{B}} \pm 0.6$ & $12.4 \pm 1.8^{\mathrm{C}}$ & $87.6 \pm 1.8^{\mathrm{A}}$ \\
\hline \multirow{2}{*}{ (T) } & T1 & $97.6 \pm 0.4$ & $3.9 \pm 0.5$ & $1.7 \pm 0.3$ & $2.3 \pm 0.4$ & $9.7 \pm 1.4$ & $4.6 \pm 0.8$ & $5.1 \pm 0.7$ & $17.5 \pm 1.8$ & $82.5 \pm 1.8$ \\
\hline & T2 & $96.5 \pm 0.6$ & $5.3 \pm 0.8$ & $1.6 \pm 0.3$ & $2.9 \pm 0.6$ & $10.5 \pm 1.7$ & $6.1 \pm 1.9$ & $4.4 \pm 0.7$ & $21.3 \pm 2.7$ & $79.7 \pm 2.7$ \\
\hline \multirow{6}{*}{$(G \times T)$} & $\mathrm{G}_{1} \times \mathrm{T}_{1}$ & $96.8 \pm 1.3$ & $5.1 \pm 0.9$ & $1.4 \pm 0.8$ & $2.1^{\mathrm{AB}} \pm 0.6$ & $13.7 \pm 2.9$ & $6.8 \pm 1.7$ & $6.9 \pm 1.3$ & $22.3^{\mathrm{B}} \pm 3.7$ & $77.7^{\mathrm{C}} \pm 3.7$ \\
\hline & $\mathbf{G}_{1} \times T_{2}$ & $95.0 \pm 2.3$ & $7.3 \pm 0.8$ & $1.7 \pm 0.3$ & $5.1^{\mathrm{A}} \pm 1.1$ & $15.7 \pm 2.4$ & $9.2 \pm 1.6$ & $6.5 \pm 1.1$ & $29.8^{\mathrm{A}} \pm 2.6$ & $70.2^{\mathrm{D}} \pm 2.6$ \\
\hline & $\mathbf{G}_{2} \times T_{1}$ & $97.3 \pm 0.8$ & $4.0 \pm 1.0$ & $1.4 \pm 0.5$ & $1.5^{\mathrm{AB}} \pm 0.3$ & $7.7 \pm 1.8$ & $3.4 \pm 0.7$ & $4.3 \pm 1.2$ & $14.6^{\mathrm{C}} \pm 2.0$ & $85.4^{\mathrm{B}} \pm 2.0$ \\
\hline & $\mathbf{G}_{2} \times T_{2}$ & $96.1 \pm 1.2$ & $5.6 \pm 1.7$ & $1.9 \pm 0.8$ & $2.4^{\mathrm{AB}} \pm 0.3$ & $12.1 \pm 1.1$ & $7.1 \pm 0.9$ & $5.0 \pm 0.7$ & $22.0^{\mathrm{B}} \pm 1.4$ & $78.0^{\mathrm{C}} \pm 1.4$ \\
\hline & $\mathbf{G}_{3} \times T_{1}$ & $98.4 \pm 0.6$ & $2.4 \pm 0.4$ & $2.2 \pm 0.4$ & $3.2^{\mathrm{B}} \pm 0.7$ & $7.8 \pm 1.6$ & $3.7 \pm 1.5$ & $4.1 \pm 0.5$ & $15.6^{\mathrm{C}} \pm 2.7$ & $84.4^{\mathrm{B}} \pm 2.7$ \\
\hline & $\mathbf{G}_{3} \times T_{2}$ & $97.7 \pm 0.5$ & $3.1 \pm 0.4$ & $1.1 \pm 0.4$ & $1.2^{\mathrm{AB}} \pm 0.8$ & $3.9 \pm 1.2$ & $2.1 \pm 0.5$ & $1.8 \pm 0.8$ & $9.3^{\mathrm{D}} \pm 1.4$ & $90.7^{\mathrm{A}} \pm 1.4$ \\
\hline ANOVA & d.f & \multicolumn{9}{|c|}{ Probabilities } \\
\hline (G) & 2 & N.S. & $* *$ & N.S. & $*$ & $* *$ & $* *$ & $* *$ & $* *$ & $*$ \\
\hline (T) & 1 & N.S. & N.S. & N.S. & N.S. & N.S. & N.S. & N.S. & N.S. & N.S. \\
\hline $\mathbf{G} \times \mathbf{T}$ & 2 & N.S. & N.S. & N.S. & $* *$ & N.S. & N.S. & N.S. & $*$ & $*$ \\
\hline Error & 18 & & & & & & & & & \\
\hline
\end{tabular}

A,B, Means within the same factor within column having different superscripts are significantly different $(\mathrm{P}<0.05)$.

N.S. $=$ Not significant, $* \mathrm{P}<0.05 ; * * \mathrm{P}<0.01$.

$\mathrm{G} 1=$ Heterozygous naked neck $(\mathrm{Na} / \mathrm{na}) \quad \mathrm{T} 1=$ High calcium level $(3.47 \%)$.

$\mathrm{G} 2=$ Homozygous naked neck $(\mathrm{Na} / \mathrm{Na}) \quad \mathrm{T} 2=$ Low calcium level $(2.51 \%)$

$\mathrm{G} 3=$ Normal feathering $(\mathrm{na} / \mathrm{na})$ 
Genotype had a significant effect on the frequency of dead embryos during incubation periods (dead 1, dead 3 and dead 4) where $\mathrm{Na} /$ - birds exhibited more dead embryos than their normal counterparts (na/na). Dietary calcium level had no siginificant effect on the distribution of embryonic mortality, since the peaks of embryonic mortality occured at 19-21 days (dead 4) and from 1-6 days (dead 1).

The highest hatchability was obtained from the normal birds (na/na) where, it was $74 \%, 81.80 \%$ and $87.6 \%$ in $\mathrm{Na} / \mathrm{Na}, \mathrm{Na} / \mathrm{na}$ and na/na genotypes, respectively. These results were in accordance with the findings of Abd El-Rahman (1997, 2000a, 2003) who reported that the presence of $\mathrm{Na}$ gene significantly reduced egg shell weight, percentage, strength and thickness. The author concluded that the adverse effect of this gene may be attributed not only to a direct gene effect but also due to that $\mathrm{Na} /$ birds are higher producer, and heavier in egg weight than their normal counterparts (na/na) and this confirm the results obtained by Clunies et al. (1992) who reported that researchers have selected birds for producing thick and thin shelled eggs.

Abd El-Rahman (2000a,b, 2003) recommended that the requirement of dietary calcium level will be changed to correct the adverse effect of the Na gene on egg shell quality which is responsible for the reduction of hatching ability in naked neck chickens $(\mathrm{Na} /-)$. Although, calcium level did not significantly affect on hatchability, the birds receiving high dietary calcium level had higher hatchability percentage $(82.5 \%)$ than those receiving low dietary calcium level (79.7\%). Attia (1993) observed that hatchability of fertile eggs was higher from hens fed $3.4 \%$ calcium level than that from $2.8 \%$ or $4 \%$ calcium level. Abou-Egla (1995) reported that eggs from chickens received $4 \%$ calcium was significantly lower in fertility and hatchability than other calcium levels (3\% and 3.5\%).

Table (4) shows that ditary calcium level had no significant effect on egg weight loss durning storage, but it significantly $(\mathrm{P}<0.01)$ affected egg weight loss during the incubation period (1-18 days) and the reduction in hatchability may be due to the effect of low calcium on shell thickness which relates to egg weight loss. Abd ElRahman $(2003,2004)$ reported that egg shell thickness was negatively correlated with egg weight loss during storage or incubation periods. Furthermore, the rate of water loss from eggs is inversely proportional to shell thickness. Peebles and Brake (1987) and Peebles et al. (1998) found that egg shell weight and thickness which are affected by calcium level were negatively correlated with the relative rate of water loss which coincided with increased embryonic mortality. Hens laid thick-shelled eggs because they retained more dietary calcium (Hurwitz, 1987).

Several explanations have been offered to account for the relationship between shell thickness and hatchability. Reduced shell thickness has been associated with increased bacterial translocation, dehydration of the embryo due to increased egg shell porosity and reduced shell strength resulting in craks, thereby increasing susceptibility to bacterial contamination and dehydration.

It can be concluded, that shell thickness which is affected by dietary calcium level is the main factor controlling egg weight loss and the embryonic mortality and hence hatchability. As shown in Table $(5)$, a significant interaction $(\mathrm{P}<0.05)$ between genotype and dietary calcium level was observed where, hatchability of the $\mathrm{Na} /-$ birds improved when birds were fed the high dietary calcium level and visa versa for the $\mathrm{na} /$ na genotype. The hatchability at high dietary calcium level $(3.47 \%)$ was $77.07 \%$, $85.40 \%$ and $84.40 \%$ for the $\mathrm{Na} / \mathrm{Na}, \mathrm{Na} / \mathrm{na}$ and na/na genotypes, respectively. The 
corresponding values from birds fed low dietary calcium level $(2.51 \%)$ were $70.20 \%$, $78 \%$ and $90.70 \%$ for the same genotypes, respectively.

Finally, high dietary calcium level $(3.47 \%)$ is important to improve the hatchability of the naked neck birds $(\mathrm{Na} /-)$ whereas the low dietary level $(2.51 \%)$ is suitable for na/na genotype under the managerial environmental conditions of this experiment.

\section{REFERENCES}

Abd El-Rahman, A., 1979. Studies on the hatchability of duck eggs. M.Sc. Assiut Univ.

Abd El-Rahman, A., 1997. Fertility, embryonic mortality and hatchability as affected by naked neck gene $(\mathrm{Na})$ and storage period in local chickens (Sharkasi) under Assiut subtropical conditions. The "Proceeding of $2{ }^{\text {nd }}$ Hungarian Egyptian Poultry Conference" 16-19 September, 1997, Godollo Hungary, pp. 273-283.

Abd El-Rahman, A., 2000a. Effect of long-term heat stress and naked neck gene (Na) on fertility, embryonic mortality and hatchability. Assiut J. of Agric. Sci., 31 (3): 135-149.

Abd El-Rahman, A., 2000b. Evaluation of egg production performance of the naked neck chickens (Sharkasi) under long-term heat stress conditions. Assiut J. of Agric. Sci. 31 (4): 269-289.

Abd El-Rahman, A., 2000c. Effect of naked neck gene (Na) and housing system on egg production performance of Sharkasi chickens under subtropical conditions. Egypt. Poult. Sci. J. 20: 905-926.

Abd El-Rahman, A., 2003. Effect of naked neck (Na) on egg weight loss, shell quality and hatching ability of Sharkasi chickens. Assiut J. of Agric. Sci. 34 (6): 53-69.

Abd El-Rahman, A., 2004. Influence of slow feathering gene (K) on egg shell quality and incubation results in Dandrawi chickens. In "Proceeding of the $4^{\text {th }}$ Scientific Conference of Agricultural Sciences", Assiut, December, 2004, pp: 775-786.

Abou-Egla, E.S., 1995. Economic evaluation of reproductive traits, egg production and egg quality for dual purposes hens fed different calcium and energy levels. Egypt. Poult. Sci. J. 15: $383-420$.

Attia, Y.A, 1993. Relationiships between calcium and energy levels on egg production and quality. PH. D. Thesis, Zagazig, University.

Balloun, S.L. and D.C. Miller, 1964. Calcium requirement of turkey breeder hens. Poult. Sci. 43: 378-381.

Basent, T.B.; S.C. Mohaptra, S.K. Agarwal and G.B. Rao, 1974. Effect of breed, season and storage temperature on fertility, to hatchability and malformations of chicken eggs. Indian J. of Poult. Sci. 9: 58-68.

Bruzual, J.J., S.D. Peak; J.T. Brake and E.D. Peebles, 2000. Effects of relative humidity during incubation on hatchability and body weight of broiler chicks from young breeder flocks. Poult. Sci. 79: 827-832.

Cherry, J. A., I. Nir., E. A. Dunnington, D.E. Jones; B. W. Cross and P. B. Seigel, 1984. Fertility and behavioral responses of roosters to diets differing in protein and calcium. Poult. Sci. 63: $863-870$. 
Clunies, M.; D. Parks and S. Leeson, 1992. Calcium and phosphorus metabolism and egg shell formation of hens fed different amounts of calcium. Poult. Sci. 71: 482489.

Davis, t.A. and R.A. Ackerman, 1987. Effects of increased water loss on growth and water content of the chick embryo. J. of Experimental Zoolg (Supplement), 1: 357-364.

Fathi, M.M., 2002. Genetic parameters for hatching performance in naked neck and normally feathered genotypes of chicken. Egypt. Poult. Sci. J. 22: 559-575.

Galal, A. and M.M. Fathi, 2003. Genetic and phenotypic parameters for hatching performance in naked neck and normally feathered dam-line of chicken. Egypt. Poult. Sci. J. 23 (2): 375-392.

Hasb El-Napy, W.A., 1989. Effect of photoperiodism and feeding regime on egg production and egg quality of the fowl. M. S. Thesis. Zagazig University.

Helmy, S.A. and M.H. Debes, 1974. The pre-incubation storage of Pekin duck eggs in plastic bags. Annuals of Agric. Sci. Fac. of Agric. Ain Shams Univ. Cairo XIX No. 1; June, 1974.

Hurwitz, S. 1987. Effect of nutrition on egg quality. Pages 235-254. In Egg Quality. Current Problems and Recent Advances. R.G. Wells and C.G. Belyavin ed. Butterworth, London U.K.

Lochuba, B.S., J. Jumar and D.D. Malik, 1971. Techniques of preservation of shell eggs under local conditions and their effect on hatchability of fertile eggs. Indian Vet. J. 48: 521-528.

Menge, H.; E.G. Geis; P.E. James, and L.T. Frabish, 1977. Effect of vitamin D3 and calcium on the reproductive characteristics of turkey hen. Poult. Sci. 46: 14721480.

Nestor, K.E.; S.P. Touchburn; M.A. Musser and E.C. Naber, 1972. Egg quality and reproduction in turkeys. 3. Variation in dietary calcium level. Poult. Sci. 51: 669677.

Peebles, E.D. and J. Brake, 1987. Egg shell quality and hatchability in broiler breeder eggs. Poult. Sci. 66: 596-604.

Peebles, E.D., J. Brake and R.P. Gildersleve, 1987. Effects of egg shell cuticle removal and incubation humidity on embryonic development and hatchability of broilers. Poult. Sci. 66: 834-840.

Peebles, E.D., T. Pansky, S.M. Doyte, C.R. Boyle, T.W. Smith, M.A. Latour and P.D. Gerad, 1998. Effects of dietary fat and egg shell cuticle removal on egg water loss and embryo growth in broiler hatching eggs. Poult. Sci. 77: 1522-1536.

Peebles, E.D., M.R. Burnham, C.W. Gardner, J. Brake, J.J. Bruzual and P.D. Gerard, 2001. Effects of incubational humidity and hen age on embryo composition in broiler hatching eggs from young breeders. Poult. Sci. 80: 1299-1304.

Roque, L. and M.C. Soares, 1994. Effect of egg shell quality and broiler breeder age on hatchability. Poult. Sci. 73: 1838-1845.

SAS Institute 1989. User's Guide Statistics. Version 6. $4^{\text {th }}$ Edition. SAS Institute Inc, Cary, NC.

Shebl, M.K. and F.N. Soliman, 1999. Role of shell and shell membrane thickness on embryonic development of chicken. Egypt. Poult. Sci. J. 19: 831-842. 
Shebl, M.K., N.A. El-Sayed, N.M. Balat and M.A. Kosba, 1996. Relationships of egg weight loss, shell porosity and shell thickness to embryonic development and specific gravity in chickens. Egypt. Poult. Sci. J. 16: 117-136.

Singh, C.V., D. Kumar and Y.P. Singh, 2001. Potential usefulness of plumage reducing naked neck $(\mathrm{Na})$ gene in poultry production at normal and high ambient temperatures. World's Poult. Sci. J. 57: 139-156.

Soliman, F.N., 2000. Effect of short pre-incubation storage period on egg weight loss embryonic development, chick weight, fertility and hatchability in two local chicken strains. Egypt. Poult. Sci. J. 20: 157-171.

Steel, R.G.D. and J.H. Torrie, 1980. Principles and Procedures of Statistics. $2^{\text {nd }}$ Ed. Mc Graw-Hill, Inc., New York, NY.

Tullett, S.G., 1990. Science and the art of incubation. Poult. Sci. 69: 1-15. 


\section{طرق تحسين نتائج الخصوية والفقس فى بيض الاجاج العارى الرقبة ( الثركسى )}

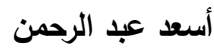

\section{قسم الإتتاج الديوانس والدواجن، كلية النزاعة، جامعة أسيوط، أسيوط}

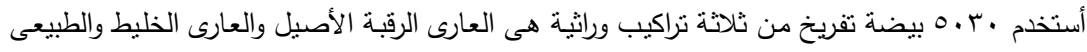

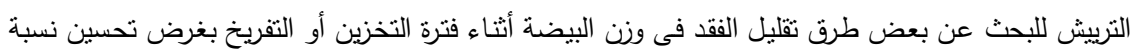

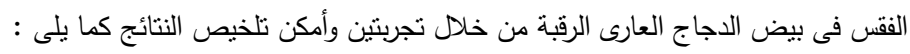

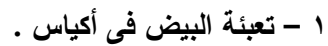

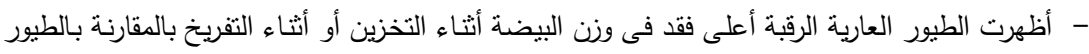
الطبيعية الترييش كما أدى تعبئة البيض إلى خفض معنى الكنى (مستوى (\%) لنسبة الفقد فى وزن البيضة .

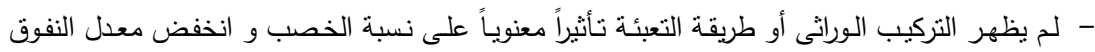

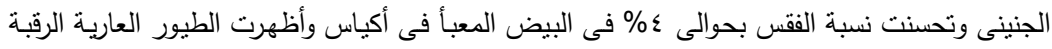

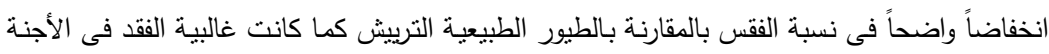

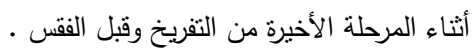

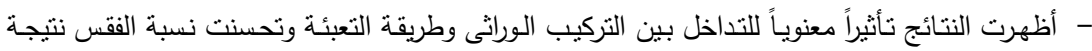

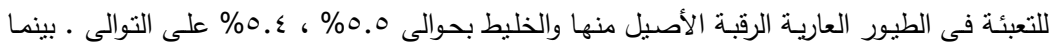

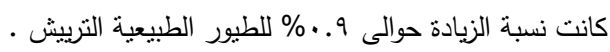

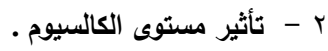

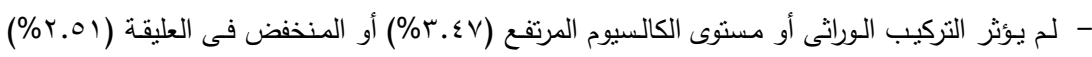

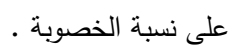

- أدى المستوى المرتفع من الكالسيوم إلى خفض في نسبة الفقد فى وزن البيضة وإلى خفض النفوق الجنينى

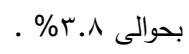

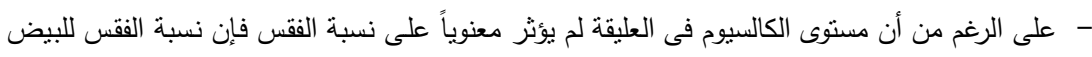

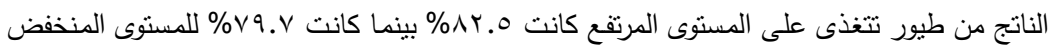

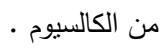

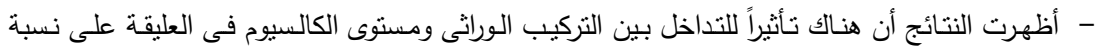

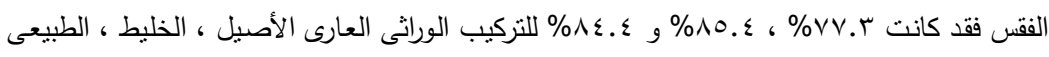

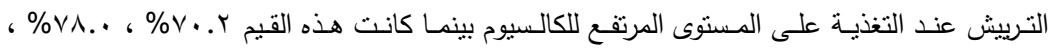

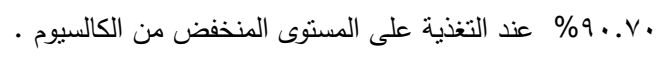




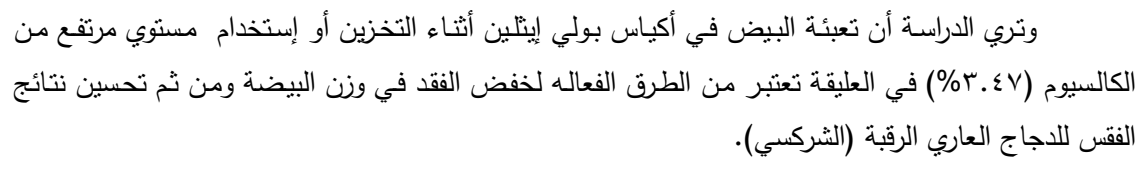

